\title{
THE POLITICS OF LUSTRATION IN UKRAINE AND POLAND (COMPARATIVE STUDY)
}

\author{
Petro Shliakhtun \\ Doctor of Philosophy, Professor, Head of Political Sciences Department, \\ Taras Shevchenko National University of Kyiv, Ukraine \\ e-mail: polit-nauk@ukr.net,orcid.org/0000-0002-7420-7325
}

\section{Ganna Malkina}

Doctor of Political Sciences, Associate Professor, Professor of Political Sciences Department,

Taras Shevchenko National University of Kyiv, Ukraine

e-mail: anna-malkina@ukr.net, orcid.org/0000-0002-2307-4702

\section{Summary}

The aim of this paper to analyse politics of lustration in Ukraine and Poland based on national and international lustration legislation. The main feature of lustration in Poland is that it was "soft" - it did not provide for the removal of a deputy's mandate or the dismissal of former functionaries of the communist regime, but only for their acknowledgment of work in state security bodies or their tacit cooperation with such bodies and only when a person submitted false information or concealed facts about such work or cooperation, they were dismissed from office with a ban on further holding responsible state positions for up to ten years. Lustration in Ukraine is analysed for compliance with the international legal acts on lustration and preliminary results are summed up following the declared objectives. lustration in Ukraine was one of the toughest in Europe. The main peculiarity of lustration in Ukraine is its introduction immediately and not soon, but almost a quarter of a century after the collapse of the communist regime and its application primarily to political rivals (officials and officers of the Yanukovych regime), rather than functionaries of the former communist regime.

Keywords: lustration, purification of power, law, political regime, political system, responsibility.

DOI: https://doi.org/10.23856/4030

\section{Introduction}

In the papers of the Ukrainian scientists, various aspects of lustration in Ukraine have been analysed in sufficient detail, and preliminary results of its implementation have been summed up. Domestic scientists considered lustration, in particular, as a way of renewal of the state power (Zadorozhny, 2017), a means of democratization of the political system of Ukraine (Turchyn, 2015), the legitimization of the new political regime, and a means of legitimization of the new political regime (Bondarenko, Zaichenko, Nagorniak, etc., 2018), prevention of corruption (Kutepov, Levitsky, 2018), an element of public control (Kravchuk, 2017), a form of political and constitutional-legal responsibility (Malkina, 2019) from its conformity with human rights (Shishkina, 2017). In this article, lustration in Ukraine is analysed in comparison with a similar process in Poland, with a view to its compliance with international legal tools on lustration and with the preliminary results of its implementation. 


\section{The politics of lustration in Post-Socialist countries}

In modern legal science, lustration (from lat. Lustratio - purification through sacrifices) is understood as a special procedure for checking people holding responsible public positions, as well as applicants for such positions, for their past cooperation with the non-democratic political regime to prevent them from assuming responsible public positions under the new democratic regime. The removal of predecessors from positions of responsibility to varying degrees occurs with any change in the political regime, which may take radical forms with the transition from an authoritarian or totalitarian to a democratic regime. Lustration has become most prevalent in the post-socialist countries of Central and Eastern Europe and the republics of the former Soviet Union, becoming independent states. In Albania, Estonia, Latvia, Lithuania, Poland, Romania, Slovakia, Hungary, the Czech Republic, and other countries, lustration was carried out to prevent former functionaries of the communist (totalitarian) regime from holding responsible government positions.

Lustration in the post-socialist countries was carried out by special authorities based on special lustration laws, which were mainly adopted in the 1990s. The lustration laws differ among themselves in terms of the scope and duration of such restrictions. Officials or candidates for a position are checked for their past membership in the leadership of communist parties, law enforcement agencies, or cooperation with such agencies.

There are two main approaches to lustration. In some countries, lustration was seen as a punishment for the guilty - those who had previously held senior positions in the Communist Party apparatus or the state security services, or had secretly cooperated with such services they were dismissed from their positions and prohibited from holding such positions for a certain period thereafter. In other countries, lustration provided for disclosure of certain actions of officials and was condemned. If an inspection carried out by special bodies established that an official had belonged in the past to the leadership of the Communist Party or state security services, or had cooperated with such services in secret, the person was allowed to choose between voluntary dismissal from office while keeping the facts secret and forced dismissal from office while disclosing such facts. In some countries, it was sufficient for officials or applicants for a responsible public position or a representative mandate to make a formal declaration of past employment with the intelligence services or of secret cooperation with them, to avoid any restriction or harassment and only if they provided false information about themselves were they released from their position and were almost barred from holding responsible public positions or participating in elections for a certain period.

In the first approach, lustration is 'hard' - all former functionaries of the communist (totalitarian) regime experience persecution for it (dismissal or avoidance of positions) without any alternative, in the second approach, 'soft' - a person only needs to confess and repent of belonging to the intelligence services or in cooperation with them to avoid any persecution. It is believed that the hardest lustration was in East Germany (the former German Democratic Republic) after it became part of the Federal Republic of Germany in 1990, and in Czechoslovakia (from 1 January 1993, in the Czech Republic, Slovakia, which became a separate state, lustration was not completed). One of the "soft" lustrations is considered to be in Poland, which was the last of the above options, although it lasted more than two decades.

Attitudes towards lustration vary from country to country and within the international community. Lustration gained the greatest support in those countries where the communist regime resorted to harsh persecution of political opposition, repression, suppression of anti-communist demonstrations, and where anti-communist sentiment was quite common at the time of 
transition to a democratic regime. At the same time, negative attitudes towards lustration were also common in democratic circles. It is perceived as an out-of-court procedure that contradicts the fundamental principles of the rule of law: the presumption of innocence, the irreversibility of laws, and the individual nature of legal liability. After all, it is the person who is put to blame for holding a particular position in the party or state apparatus, especially in law enforcement agencies, regardless of the specific content of her activities. And guilt is established by a law adopted after such activity and all such officials, not individuals, are declared guilty in advance.

Despite the ambiguous perception of lustration, its legitimacy has been recognised by the international community. On 27 June 1996, the Parliamentary Assembly of the Council of Europe (PACE) adopted Resolution 1096 (1996) on "Measures to dismantle the heritage of former communist totalitarian systems", which sets out the main provisions and principles on lustration (Rezoliutsiia 1096 (1996). The report annexed to the Resolution contains "Guidelines to ensure that lustration laws and similar administrative measures comply with the requirements of a state based on the rule of law".

\section{The politics of lustration in Poland}

Taking into account the above mentioned about lustration and these international legal acts, we will analyse the experience of its implementation in Poland as a country that is territorially, mentally, and politically close to Ukraine and in Ukraine itself in comparison with the Polish experience.

In Poland, the beginning of the transition from communism (socialism) to parliamentary democracy was the result of the so-called Round Table - negotiations on the future of the country between the trade union movement and members of the Communist Party's (Polish United Labour Party, PULP) Politburo in the first half of 1989. As a result of the negotiations, constitutional changes were initiated in the country. In January 1990, the PULP dissolved itself (as its successor, the Social Democracy Party of the Republic of Poland was established). Following the 1990 presidential elections, the first Polish president was Lech Walesa, the leader of the Solidarity trade union, an opposition communist power organisation. The peaceful change of power in Poland led to the "soft" nature of the lustration carried out in the country.

With the change of power in the country, the idea of lustration is gaining popularity. Initially, the idea was to make it impossible for people involved in the infringement of citizens' rights and freedoms in communist Poland to occupy responsible positions in public administration and local government. The first lustration bills appeared in the Polish Parliament in December 1991 but were not considered. At the end of May 1992, the Polish Sejm, the lower house of Parliament, adopted a decision obliging the Minister of the Interior to provide him with archived information about civil servants, deputies (members of the Sejm), and senators (members of the upper house of Parliament - the Senate), as well as judges, prosecutors, and lawyers. From 1945 to 1990, they were informants for the security service of the Ministry of the Interior or collaborated in any other form with the special services.

At the beginning of June 1992, the so-called "Macierewicz list" was made public, named after the then Interior Minister Antoni Macierewicz, who caused a political crisis in the country and led to the resignation of the government. The list, which was compiled according to archival data from 66 people, included the names of many famous politicians from the Solidarity trade union, including Lech Walesa, who, according to archival data, cooperated with Polish intelligence services at various times. A political scandal flared up. Polish President Lech Walesa initiated the resignation of the government by the Parliament on 5 June 1992 and 
appealed the lustration decision of the Parliament before the Constitutional Tribunal. The list was seen as controversial because it was only a list of names, without specifying when, how long, and in what forms their bearers collaborated with the intelligence services. The Constitutional Court declared the lustration decision unconstitutional and prohibited any legal action based on the list. The lustration problem became an instrument of political struggle not between communists, who had dropped out of the political arena, and the new authorities, but between representatives of the former anti-communist opposition, which in the early 90 s was divided into right-wing and leftist political forces (Zinchenko, 2013).

Between 1992 and 1996, six bills on lustration were submitted to the Sejm, but none of them were approved (Rafal, 2015). The first lustration law in Poland was adopted only in 1997, and the term "lustration" is not used in its title "Act of 11 April 1997 on Disclosure of Employment or Service in State Security Bodies or Cooperation with them in 1944-1990 of Persons Performing Public Functions" (Dziennik Ustaw, 1997), as is the case with similar laws in other countries. The Act provided for the verification of persons elected to Parliament who held responsible public positions or claimed to hold such positions for their work in the Polish state security bodies or for their cooperation with such bodies between 22 July 1944 and 10 May 1990. According to the Act, lustration tests were to be carried out by the President, members of the Government, parliamentarians, deputies and local government officials, judges, prosecutors, lawyers, rectors and vice-rectors of higher education institutions, employees of all educational supervisors, chief editors and department heads of central and regional media. Persons born after 31 July 1972 were not subject to inspection.

The inspection procedures were that the person to be inspected had to draw up a lustration declaration of any form of work or cooperation with the state security authorities or the lack of such work or cooperation and file it with the lustration court established at the Court of Appeal in Warsaw. The submission of the declaration and its verification was supervised by a special official - the Public Interest Ombudsman (Rzecznik Interesu Publicznego) (aka the lustration prosecutor). The Public Interest Ombudsman assessed the lustration declarations and determined their authenticity; if there was any doubt about the authenticity of the information provided, he carried out an independent investigation and was granted unrestricted access to all archives of the state security authorities. A positive declaration, i.e. a statement of facts about work in the state security authorities or cooperation with them, was perceived as repentance and did not itself cause any legal consequences. And only in the case of untruthful information about oneself or concealing information about work in state security bodies or secret cooperation with such bodies did a person lose her mandate by a decision of the Public Interest Ombudsman to the court, or was dismissed from her post with a ban on holding civil service positions for three to 10 subsequent years. Not only deputies, senators, and persons who held responsible public positions, but also applicants for election or appointment to such positions were subject to lustration tests. The decision of the lustration court could be appealed to the court of the second instance.

By 1999, approximately 23,000 people had undergone lustration in Poland, according to various estimates (official statistics were never published), and about two percent of all declarations were positive (Vasilchenko, 2019).

After the right-liberal forces came to power in Poland in 2005 (in October 2005 Lech Kaczyński was elected as President of Poland, and following the parliamentary elections the political party "Law and Justice" headed by his brother Jarosław Kaczyński gained a relative majority in the Parliament and coalition with two other conservative political parties formed the government) the Sejm passed a new, stricter, lustration law: "Act of 18 October 2006 on the 
disclosure of documents of the state security bodies of the Republic of Poland. According to the new law, the lustration process has undergone significant changes. The Lustration Court and the position of the Public Interest Ombudsman were abolished, the circle of persons who had to undergo lustration inspection was expanded, the date of possible cooperation with the state security authorities was shifted from 10 May 1990 to 31 July 1990, and the institute of judicial appeal against a lustration decision was abolished. The circle of persons' subject to lustration testing also included heads of local authorities, members of the management of state-owned companies, chief editors and journalists of all Polish media, all scientific staff of universities, researchers of the Polish Academy of Sciences, directors of public schools, tax auditors, bailiffs, heads of sports associations, which increased their number significantly - to 700,000. However, in terms of content, the new law, like the previous one, provided for a penalty of suspension from office only if false information is reported or if the information is concealed.

In May 2007, the Polish Constitutional Court partially declared the lustration law unconstitutional, which made the lustration law invalid in this part. Employees of education, science, mass media, and entrepreneurs were exempt from lustration. At the same time, the Constitutional Court recognised as constitutional a provision of the law obliging almost 30,000 officials who had to undergo lustration tests under the 1997 law to undergo lustration again, as one of the innovations of the new lustration law provides for a more detailed definition of forms of cooperation with the state security authorities. Persons who refuse to undergo lustration lose the right to engage in their professional activities (Dziennik Ustaw, 2006).

The lustration inspection authority was granted to a special institution called the Institute of National Remembrance - Commission for the Prosecution of Crimes against the Polish Nation (IPN), which had a lustration bureau assigned to it. The Institute was granted investigative functions and the possibility of criminal proceedings against crimes committed against the Polish people by both Nazis and Communists, and a large part of the archives of the IPN state security bodies were handed over to it. Employees of the Public Prosecutor's Office (public prosecutors) of the IPN are obliged to check all lustration declarations for their accuracy. The Lustration Act of 18 October 2006, as amended, is still in force in Poland, but the IPN does not disclose official data on the number of lustrators, referring to the need to protect personal data.

\section{The Politics of lustration in Ukraine}

In Ukraine, as in Poland, the transition from a communist regime to a democratic one did not involve revolutionary shocks. However, unlike in Poland, in Ukraine, the former communist regime functionaries remained in power for a long time. Leonid Kravchuk, former secretary of the Central Committee of the Communist Party of Ukraine, became Chairman of the Verkhovna Rada of Ukraine, and on $1^{\text {st }}$ of December 1991, he was elected the first President of Ukraine. The idea of lustration to remove the Communists from power and prevent them from coming to power in the future was not popular in Ukrainian society. The lustration requirement was put forward only by nationalist (democratic and radical) political forces, whose representatives repeatedly submitted lustration bills to the Verkhovna Rada of Ukraine, but they did not find support for the following.

The idea of lustration was most consistently advocated by the radical nationalist political party All-Ukrainian Freedom Association. Lustration became one of the most important program tasks of this party. Freedom" was able to realize this task in the Verkhovna Rada of Ukraine only after the change of power in Ukraine as a result of mass protests in November 2013 
February 2014 (i.e. Euromaidan), which received the official (enshrined in Ukrainian legislation) name "Revolution of Dignity". The radicalisation of public sentiment as a result of the 'Revolution of Dignity', the demoralisation of people's deputies from the ruling Party of Regions in connection with the shooting of protesters in the capital, the dissolution of the Communist Party of Ukraine faction, and the reformatting of the parliamentary majority in the Verkhovna Rada of Ukraine created favourable conditions for the adoption of a law on lustration, which was done even before the extraordinary parliamentary elections in October 2014. On 16 September 2014, the Verkhovna Rada of Ukraine adopted the Law of Ukraine "On Purification of Power". (Zakon Ukrainy, 2014). The law was passed under pressure from Euromaidan activists who had gathered outside the parliament building.

While the new Polish government slowed down with the introduction of lustration by seven years (the first lustration law was passed in 1997), the Ukrainian government was 23 years late with the introduction of lustration, which determined its main features. Whereas in Poland lustration was applied to elected and public officials only for work in the past in state security bodies or cooperation with such bodies and the case of their honest recognition in such work or cooperation had no legal consequences for them, in Ukraine lustration consisted in relieving people from their positions with a ban on further employment for five or ten years.

The Law of Ukraine "On the Purification of Power" has introduced a ban on holding public positions specified by the law for ten years to persons who during the period from February 25, 2010, to February 22, 2014 (this is the time of Viktor Yanukovych's presidency for more than one year, as well as to persons who held positions specified by the law for less than one year, but including the period from November 21, 2013 (the day when the Cabinet of Ministers of Ukraine announced the decision to suspend preparations for the signing of the Association Agreement of Ukraine with the European Union and the beginning of the process). Also, persons who held senior positions in the Communist Party of the Soviet Union or the party of one of the Union republics, starting from the position of secretary of the district committee of the party and above, in Komsomol organizations, were regular employees or tacit agents of the State Security Committee of the USSR or the Union Republic, the Main Intelligence Directorate of the Ministry of Defense of the USSR, are subject to lustration (prohibition to hold certain public positions).

This means that the main feature of lustration in Ukraine, again in contrast to lustration in Poland, was that it was used not so much by the functionaries of the former communist regime, most of whom no longer held any senior positions or even went to the other world, but rather against their political rivals - officials of the previous "Yanukovych's regime", that is, it was used primarily as a tool of political struggle. This is clearly stated in the law "On the Purification of Power": "Purification of power (lustration) is carried out to prevent persons who by their decisions, actions or omissions carried out activities (and/or contributed to their commission) aimed at the usurpation of power by the President of Ukraine Viktor Yanukovych, undermining the foundations of national security and defense of Ukraine or illegal violation of human rights and freedoms ..." (Part 2 Article 1).

The timing and direction of lustration in Ukraine directly contradict the documents of the Parliamentary Assembly of the Council of Europe on lustration issues. Indeed, Resolution 1096 (1996) "On measures to eliminate the legacy of former communist totalitarian systems" of PACE, as it is already clear from its name, refers to measures to eliminate the legacy of the former communist totalitarian systems and emphasizes that "A democratic state based on rule of law, has sufficient means to serve the cause of justice and punish those responsibly, but it cannot and should not give in to the desire to take revenge instead of seeking justice" (cl. 4), 
and the" Guidelines to ensure that lustration laws and similar administrative measures comply with the requirements of a state based on the rule of law "stipulate that" lustration can only be applied to actions, employment or membership in organizations that took place from January 1 , 1980, until the overthrow of the communist dictatorship" (cl. 12).

Since its inception, lustration in Ukraine has worked as a means of implementing the political responsibility of the functionaries of the previous political regime ("Yanukovych's regime") and legitimizing the new political regime. Over time, however, it began to lose its effectiveness in both respects. Due to the imperfection of lustration mechanisms, the existence of loopholes to avoid liability of officials and officers (participation in the anti-terrorist operation, the right of the President of Ukraine to dismiss certain categories of persons from liability by a lustration, the possibility to appeal against the application of lustration measures in court, corporate solidarity), lustration covered a much smaller number of persons than it was intended.

Lustration activities were coordinated by the Department for Lustration, which was specially created for this purpose within the Ministry of Justice of Ukraine. Under the Ministry of Justice, with the participation of the Public Lustration Committee, a special 12 persons' body, the Public Council on Lustration, was established on a competitive basis. The Ministry of Justice created the Unified State Register of Persons concerning whom the provisions of the Law of Ukraine "On the purification of power" have been applied. In the public authorities, lustration was carried out by specially created commissions from representatives of the new authorities and public organisations - mainly active participants in the Euromaidan.

Initially, it was assumed that about 700,000 officials would be subject to lustration (300,000 of whom were civil servants, subject to inspection), including about five thousand officials who fell under the criterion of automatic release through high offices during the presidency of Viktor Yanukovych. Since the opening of the register of lustrated persons, the number of lustrated (discharged) persons in the register has increased and exceeded 900 persons, after which it began to decrease (due to the removal from the register of persons whose lustration decision was annulled, including by courts, and the names of deceased persons). This means that lustration as the removal of people from their positions has stopped in Ukraine. However, it continues to be implemented as a ban on specific persons from holding positions for five or ten years. Official data on the total number of lustrated persons has not been announced.

One of the main tasks of lustration in Ukraine, which is typical for lustration in Poland, was to overcome corruption. According to the Law of Ukraine "On the purification of power", the prohibition to hold office for ten years also applies to persons who have been inspected to find that their declared information about their property, income, and expenses is not reliable and/or that the declared value of the property acquired during their stay in positions for which lustration measures are being taken and the income received from legal sources is not consistent (Part 8 Article 3). Such discrepancy means illegal enrichment and is considered a criminal offence.

Law enforcement agencies have opened dozens of criminal proceedings under Article 3682 (illegal enrichment) of the Criminal Code of Ukraine, and some of the relevant cases have already been referred to court. However, high hopes for overcoming corruption and bringing officials and deputies to criminal responsibility for illegal enrichment did not come true, because the Constitutional Court of Ukraine by its decision of February 26, 2019, recognized the article on illegal enrichment of the Criminal Code of Ukraine as such that does not comply with the Constitution of Ukraine (is unconstitutional) and loses force from the date of the Constitutional Court of Ukraine's decision. According to this decision of the Constitutional Court of Ukraine, the investigation and judicial proceedings on the illegal enrichment were terminated without the possibility of their restoration. 
An opinion of the European Commission for Democracy through Law (Venice Commission) has been received on the Law of Ukraine "On Purification of Power", which contains many comments on the law and formulates several recommendations for its improvement. However, despite repeated promises, the new Ukrainian government has not made any changes to the Law on Purification of Power.

During November 2014 - March 2015, the Constitutional Court of Ukraine received three appeals (two from the Supreme Court of Ukraine and a friend from 47 people's deputies of Ukraine) with a proposal to consider the question of compliance with the Constitution of Ukraine (constitutionality) of certain provisions of the Law of Ukraine "On Purification of Power" and to provide an official interpretation of some provisions of this law. The Constitutional Court of Ukraine merged the three appeals proceedings into one constitutional proceeding, which was never decided. Not least because of the pressure exerted on it by nationalist forces, whose activists have repeatedly staged protests outside the court building. Still, the main reason why the Constitutional Court of Ukraine delayed the decision on the constitutionality of the law "On Purification of Power" is that the court is faced with an intractable dilemma to recognize this law as constitutional through its obvious contradiction to the Constitution of Ukraine and, in general, to the fundamental principles of the state based on the rule of law, and at the same time cannot recognize it as unconstitutional, because such recognition will have difficult legal and financial consequences for the state, as it will have to be renewed in the position of the lustrator.

The failure to complete the lustration drama in Ukraine is not only due to the inaction of the Constitutional Court. Its new act is connected with the consideration of complaints from lustre citizens of Ukraine to the European Court of Human Rights (ECHR). As you know, the ECHR considers complaints from citizens of the Council of Europe member states about violations of their rights under the 1950 European Convention for the Protection of Human Rights and Fundamental Freedoms adopted by the Council of Europe. By the Convention, a court may only take a case to consideration after all domestic remedies have been exhausted.

Lustrated citizens of the Council of Europe member states have repeatedly lodged complaints with the ECHR and it has mostly satisfied such complaints. It is now up to the lustrated citizens of Ukraine to consider their complaints.

The most famous in Ukraine was the decision of the ECHR in the case "Polyah and others v. Ukraine", published on 17 October 2019. Applicants in the case were five citizens of Ukraine, three of whom were dismissed from their posts by the Law of Ukraine "On Purification of Power" in October 2014 because they held positions in public service in 2010-2014 under the presidency of Viktor Yanukovych, one - for applying for lustration inspection, another - for the fact that he held the post of Second Secretary of the District Committee of the Communist Party of Ukraine until 1991. In its judgment in the case, the ECHR found that there were violations of Article 6 (right to a fair trial) due to too long examination of the cases of three applicants at the national level and Article 8 (right to respect for private and family life) of the Convention in respect of all five applicants.

The Court ruled that Ukraine should reimburse each applicant for moral damages and court costs in certain amounts. The ECHR held that the Law of Ukraine "On Purification of Power" applied to a very wide range of persons and led to the applicants' dismissal on the sole ground that they had held public office for more than a year during Viktor Yanukovych's presidency, or based on holding positions in the party until 1991. In the Court's opinion, the Act did not take into account the personal role played by the petitioners or whether they were personally involved in any undemocratic activities under the former President. 


\section{Conclusions}

Although lustration contradicts the fundamental principles of the rule of law (presumption of innocence, irreversibility of laws, individual nature of legal responsibility), it is considered justified in post-socialist countries given the need to remove the functionaries of the previous communist (totalitarian) regime from power and to establish a democratic political regime. The legal basis for lustration is provided by the PACE acts: Resolution 1096 (1996) on measures to eliminate the legacy of the former communist totalitarian systems and Guidelines to ensure that lustration laws and similar administrative measures comply with the requirements of a state based on the rule of law, which justifies the lawfulness of lustration and at the same time contain certain caveats for its implementation.

The main feature of lustration in Poland is that it was "soft" - it did not provide for the removal of a deputy's mandate or the dismissal of former functionaries of the communist regime, but only for their acknowledgment of work in state security bodies or their tacit cooperation with such bodies and only when a person submitted false information or concealed facts about such work or cooperation, they were dismissed from office with a ban on further holding responsible state positions for up to ten years.

By contrast, lustration in Ukraine was one of the toughest in Europe. The main peculiarity of lustration in Ukraine is its introduction immediately and not soon, but almost a quarter of a century after the collapse of the communist regime and its application primarily to political rivals (officials and officers of the Yanukovych regime), rather than functionaries of the former communist regime. Such peculiarities of lustration in Ukraine are associated with mass protests in the winter of 2013-2014 and the change of power in Ukraine in February 2014, which was called the "Revolution of Dignity". Despite the radicalism of the Law of Ukraine "On Purification of Power" and active lustration activities, it has not yet been possible to achieve the main goals declared by it - purification of the authorities from the functionaries of the former regime, and especially - overcoming corruption. The Law of Ukraine 'On Purification of Power' requires further improvement in terms of compliance with the principles of the legal state and international legal acts on lustration, as well as verification by the Constitutional Court of Ukraine for compliance with the Constitution of Ukraine.

\section{References}

Bondarenko, S., Zaichenko, T., Nagorniak, N. (2018). Liustratsiia v Ukraini yak zasib lehitymatsii novoho politychnoho rezhymu [Lustration as a tool of legitimization of new political regime]. Politychne zhyttia. No.2. [in Ukrainian].

Dziennik Ustaw. (1997). Ustava z dnia 11 kwietnia 1997 r. o ujawnieniu pracy lub sluzbi $w$ organach bezpieczenstwa panstwa lub wspolpracy z nimi w latach 1944-1990 osob pelniacych funkcje publiczne (Dziennik Ustaw. 1997 nr 70 poz. 443) / Internetowy System Aktow prawnych. [Electronic resource]. Retrieved from: http://isap.sejm.gov.pl/DetailsServlet? id=WDU19970700443. [in Polish].

Dziennik Ustaw. (2006). Ustava z dnia 18 pazdziernika 2006 r. o ujawnieniu informacji o dokumentach organow bezpieczenstwa panstwa lat 1944-1990 oraz tresci tych dokumentow // Dziennik Ustaw. 218. S.10809-10837 / Internetowy System Aktow prawnych. [Electronic resource]. Retrieved from: http://isap.sejm.gov.pl/DetailsServlet?id=WDU20062181592+ 2007\%2403\%2415\&min=1. [in Polish]. 
Kovalchuk, V. (2017). Liustratsiia yak mekhanizm zakhystu osnov demokratii ta prav liudyny $v$ Ukraini. [Lustration as a mechanism for protecting the foundations of democracy and human rights in Ukraine]. Visnyk Natsionalnoho universytetu "Lvivska politekhnika". Yurydychni nauky. No. 865. [in Ukrainian].

Kutepov, M., Levitsky, S. (2018). Liustratsiia yak zasib zapobihannia koruptsii [Lustration as a tool of prevention of corruption]. Molodyi vchenyi., No. 1(2). [in Ukrainian].

Malkina, G. (2019). Liustratsiia yak forma politychnoi vidpovidalnosti v Ukraini [Lustration as a form of political responsibility in Ukraine]. Virtus: Scientific Journal. No.32. [in Ukrainian]. Rafal, A. (2015). Рафал Анастасия. Kak prokhodyla liustratsyia v Polshe: "Razvedku y kontrrazvedku mbl sozdaly praktychesky zanovo". [As the lustration took place in Poland: "We have created intelligence and counterintelligence almost anew."]. [Electronic resource]. Retrieved from: cripo.com.ua/processes/?p=205801/. [in Russian].

Rezoliutsiia 1096 (1996) "Pro zakhody shchodo likvidatsii spadshchyny kolyshnikh komunistychnykh totalitarnykh system”. Parlamentska asambleia Rady Yevropy. [Resolution 1096 (1996) "On measures to eliminate the legacy of the former communist totalitarian systems". Parliamentary Assembly of the Council of Europe]. [Electronic resource]. Retrieved from: http://www. viaduk.net/clients/vsu/vsu.nsf/(documents)/9CCC052FF67F623FC2257D9E0041D022?OpenDocument\&Highlight=0,\%EF\%F0\%EE. [in Ukrainian].

Shishkina, E. (2017). Liustratsiia i prava liudyny [Lustratia and human rights]. Naukovi zapysky NaUKMA. Yurydychni nauky. - Vol. 200. [in Ukrainian].

Turchyn, Y. (2015). Liustratsiia yak zasib demokratyzatsii politychnoi systemy Ukrainy [Lustration as a tool of political system democratization in Ukraine]. Humanitarian Vision. - Vol. 1, No. 1. [in Ukrainian].

Vasilchenko, V. (2019). Liustratsyia ne to, chem ona kazhetsia. Kak stranbl Vostochnoi Evropy razbyralys so svoym nedavnym proshlym. [Lustration is not what it seems. How the countries of Eastern Europe dealt with their recent past]. [Electronic resource]. Retrieved from: zona. media/article/2019/11/13/lustratio. [in Russian].

Vodo, V., Gabuev, A. (2007). Zakon o svobode proshloho. V Polshe peresmotrely zakon "O liustratsyy". [The law of freedom of the past. In Poland, the law "On lustration" was revised]. [Electronic resource]. Retrieved from: kommersant.ru/doc/765201. [in Russian].

Zadorozhny, Y.A. (2017). Liustratsiia yak sposib onovlennia derzhavnoi vlady [Lustration as a tool of state power renovation]. Naukovyi visnyk Uzhhorodskoho natsionalnoho universytetu. Seriia : Pravo. - Vol. 44(1). [in Ukrainian].

Zakon Ukrainy (2014) Pro ochyshchennia vlady No. 1682-VII. [Law of Ukraine on Purification of Power]. [Electronic resource]. Retrieved from: ttp://zakon4.rada.gov.ua/laws/show/1682-18. [in Ukrainian].

Zinchenko, A. (2013). Pochemu Polshe udalos? Liustratsyia y obshchaia dekommunyzatsyia kak эkonomycheskye faktorbl. Chast 2. [Why did Poland succeed? Lustration and general decommunization as economic factors. Part 2.]. [Electronic resource]. Retrieved from: http://argumentua.com/stati/pochemu-polshe-udalos-lyustratsiya-i-obshchaya-dekommunizatsiya-kak-ekonomicheskie-faktory-cha. [in Russian]. 